\title{
Restoration of optic neuropathy
}

This article was published in the following Dove Press journal:

Journal of Neurorestoratology

15 March 2017

Number of times this article has been viewed

\section{Si-Wei You' \\ Ming-Mei Wu ${ }^{2}$ \\ Fang Kuang ${ }^{2}$ \\ Kin-Sang $\mathrm{Cho}^{3}$ \\ Kwok-Fai So ${ }^{4,5}$}

'Department of Ophthalmology, Xijing Hospital, 'Institute of Neurosciences, The Fourth Military Medical University, Xi'an, China; ${ }^{3}$ Schepens Eye Research Institute, Massachusetts Eye and Ear, Department of Ophthalmology, Harvard Medical School, Boston, MA, USA; ${ }^{4}$ GHM Institute of CNS Regeneration, Key Laboratory of Brain Function and Diseases, Jinan University, Guangzhou, ${ }^{5}$ Department of Ophthalmology, The State Key laboratory of Brain and Cognitive Sciences, The University of Hong Kong, Hong Kong SAR, China

Correspondence: Si-Wei You Department of Ophthalmology, Xijing Hospital, 127 Changle Xi Road, Xi'an 710032, China

Tel +862984776756

Email yousiwei@hotmail.com
Abstract: Optic neuropathy refers to disorders involving the optic nerve $(\mathrm{ON})$. Any damage to $\mathrm{ON}$ or ON-deriving neurons, the retinal ganglion cells (RGCs), may lead to the breakdown of the optical signal transmission from the eye to the brain, thus resulting in a partial or complete vision loss. The causes of optic neuropathy include trauma, ischemia, inflammation, compression, infiltration, and mitochondrial damages. ON injuries include primary and secondary injuries. During these injury phases, various factors orchestrate injured axons to die back and become unable to regenerate, and these factors could be divided into two categories: extrinsic and intrinsic. Extrinsic inhibitory factors refer to the environmental conditions that influence the regeneration of injured axons. The presence of myelin inhibitors and glial scar, lack of neurotrophic factors, and inflammation mediated by injury are regarded as these extrinsic factors. Extrinsic factors need to trigger the intracellular signals to exert inhibitory effect. Proper regulation of these intracellular signals has been shown to be beneficial to ON regeneration. Intrinsic factors of RGCs are the pivotal reasons that inhibit $\mathrm{ON}$ regeneration and are closely linked with extrinsic factors. Intracellular cyclic adenosine monophosphate (cAMP) and calcium levels affect axon guidance and growth cone response to guidance molecules. Many genes, such as Bcl-2, PTEN, and $m T O R$, are crucial in cell proliferation, axon guidance, and growth during development, and play important roles in the regeneration and extension of RGC axons. With transgenic mice and related gene regulations, robust regeneration of RGC axons has been observed after ON injury in laboratories. Although various means of experimental treatments such as cell transplantation and gene therapy have achieved significant progress in neuronal survival, axonal regeneration, and restoration of the visual function after ON injury, many unresolved scientific problems still exist for their clinical applications. Therefore, we still need to overcome hurdles before developing effective therapy to treat optic neuropathy diseases in patients.

Keywords: retinal ganglion cells, optic nerve injury, neuronal survival, axonal regeneration, vision restoration

Optic neuropathy refers to disorders involving the optic nerve (ON). Because ON transmits optical signals from the eye to the brain, any damage to $\mathrm{ON}$ or ON-deriving neurons, the retinal ganglion cells (RGCs), may lead to the breakdown of this transmission, thus resulting in loss of visual field and eventually partial or complete vision loss. The causes of optic neuropathy include trauma, ischemia, inflammation, compression, infiltration, and mitochondrial damages (nutritional, toxic, and hereditary).

Primary ON injuries, such as mechanical perturbance, ischemia, hypoxia, and inflammation, lead to direct axonal damage, while secondary injury may exacerbate the damage by complicated mechanisms including immune reaction, oxidative free radicals, and excitatory cellular toxicity. During these injury phases, various factors 
orchestrate injured axons to die back and become unable to regenerate, and these factors could be divided into two categories: extrinsic and intrinsic.

Extrinsic inhibitory factors refer to all conditions in the ON but outside RGCs, namely the environmental conditions that influence the regeneration of injured axons. Lack of neurotrophic factors, the presence of myelin inhibitors, and glial scar composed of chondroitin sulfate proteoglycans (CSPGs) are being investigated. Inflammation mediated by injury including immune cell infiltrations is also included as an extrinsic factor, but is more complicated. Intrinsic factors of RGCs are the pivotal reasons that inhibit $\mathrm{ON}$ regeneration and are closely linked with extrinsic factors. Intracellular cyclic adenosine monophosphate (cAMP) and calcium levels affect axon guidance and growth cone response to guidance molecules. Extrinsic factors need to trigger the intracellular signals to exert inhibitory effect. Guanosine triphosphatase (GTPase) and Ras homolog gene family member A (RhoA) - a small GTPase, involved signals are associated with myelin-associated glycoprotein (MAG) and other myelinderived inhibitory factors in axonal regeneration. Proper regulation of these intracellular signals has been shown to be beneficial to $\mathrm{ON}$ regeneration. Recent research works found that many genes, usually playing roles in cell proliferation, axon guidance or growth during development, were downregulated after development and played important roles in the regeneration and extension of RGC axons. These genes include B-cell lymphoma 2 ( $\mathrm{Bcl}-2)$, phosphatase and tensin homolog $(P T E N)$, and the mammalian target of rapamycin (mTOR). With transgenic mice and related gene regulations, robust regeneration of RGC axons has been observed after ON injury in laboratories. ${ }^{1-3}$

Although various means of experimental treatments such as cell transplantation and gene therapy have achieved significant progress in neuronal survival, axonal regeneration, and restoration of the visual function after ON injury, many unresolved scientific problems still exist for their clinical applications. Therefore, more time is needed before the aim of clinical applications of these effective therapeutic methods is achieved.

\section{Experimental neurorestorative studies \\ Factors and medicine}

\section{Anti-myelin-derived inhibitors}

The use of anti-myelin-derived inhibitors is an important strategy for ON regeneration. Techniques include antibodies, antisense oligonucleotide, gene knockout, interruption of ligand-receptor combination, and blockage of associated signal pathway.

Nogo-A is one of the most potent oligodendrocyte-derived inhibitors for axonal regrowth in injured adult cerebral nervous system (CNS). Using an anti-Nogo-A antibody or by expressing a dominant-negative form of the Nogo receptor $(\mathrm{NgR})$ in RGCs can block the activity of Nogo. However, Cui et al found that application of IN-1, an antibody against Nogo, alone failed to enhance regeneration of transected RGC axons in a peripheral nerve (PN) graft. IN-1 hybridoma cells also failed to significantly promote crushed $\mathrm{ON}$ axons to reenter the distal part of the ON. However, a combined application of IN-1 and ciliary neurotrophic factor (CNTF) had a synergistic effect in $\mathrm{ON}$ crush paradigms, suggesting that the action of IN-1 antibodies in promoting axonal regeneration in the CNS could be more effective when coupled with other appropriate factors. ${ }^{4} \mathrm{Su}$ et al demonstrated that Nogo-Adeficient mice showed significantly longer axon regrowth than control, according to growth-associated protein-43 immunohistochemistry and Nogo-A/B/C knockout resulted in more active regeneration of RGC axons, and suggested Nogo knockout could be an effective way to eliminate this inhibition and accelerate axonal regeneration. ${ }^{5}$ Knockout of the Nogo-66 receptor enhanced regeneration after ON crush. ${ }^{6}$

Counteracting the $\mathrm{NgR}$ enhances $\mathrm{ON}$ regeneration if RGCs are in an active growth state, but when the growth program of RGCs is not activated, the negative form of the NgR would not have any beneficial effect. ${ }^{7}$ Chen inhibited $\mathrm{NgR}$ by RNA interference and recruited exogenous trophic support by the zymosan intravitreal injection and found that either approach can stimulate $\mathrm{ON}$ axonal regrowth but regenerating axons can grow longer and extend further when both methods were combined. ${ }^{8}$ When associated with $\mathrm{NgR}$, the transmembrane receptor p75NTR signals the collapse of growth cones. Ahmed et al showed that the in vivo ON regeneration correlates with Schwann cell-derived factor-induced cleavage of NgR and Nogo-A, and inactivation of p75NTR signaling by the induction of regulated intramembranous proteolysis and the release of both extracellular (p75ECD) and intracellular (p75ICD) domains. Schwann cell-derived factor induced attenuation of NgR/p75NTR signaling which in turn suppressed epidermal growth factor receptor (EGFR) activation, thereby potentiating the disinhibition of axonal growth. ${ }^{9}$

Interfering with RhoA is a more comprehensive way to overcome inhibitory signals. RhoA is a small GTPase that is part of the intracellular signaling pathway through which multiple inhibitors cause the collapse of growth cone and 
arrest axonal growth. Inhibition of RhoA results in modest levels of axonal regeneration of injured $\mathrm{ON}$, while blockade of Rho-associated coil-forming protein kinase (ROCK) promotes the neurite outgrowth of adult RGCs only in the presence of growth-promoting factors. ${ }^{10} \mathrm{Bcl}$-2-associated athanogene-1 (BAG1) is an Hsp70/Hsc70-binding protein which can suppress apoptosis and enhance neuronal differentiation. Planchamp et al demonstrated that BAG1 induced an intracellular translocation of Raf-1 (an enzyme, a member of Raf family which belongs to MAP kinase kinase) and ROCK2 and ROCK activity was decreased in a Raf-1-dependent manner by BAG1's overexpression. Therefore, BAG1 promotes axonal outgrowth and regeneration in vivo via Raf-1 and reduction of ROCK activity. ${ }^{11}$

MAG is involved both in the initiation of myelination in the $\mathrm{CNS}^{12}$ and in the events of cell adhesion during $\mathrm{ON}$ regeneration. ${ }^{13}$ MAG is necessary for the maintenance of the cytoplasmic collar and periaxonal space of myelinated fibers. ${ }^{14}$ Axonal regeneration in the CNS of adult MAGdeficient mice was not improved when compared to wild-type animals, ${ }^{15}$ but inactivation of MAG enhances ON regeneration. Wong et al used the retina-ON explants of embryonic chicks and eliminated MAG function acutely along ON using chromophore-assisted laser inactivation (CALI). They found that CALI of MAG permitted significant regrowth of retinal axons passing the lesion site of the CNS. ${ }^{16}$

CSPG, a matrix protein that occurs naturally in the CNS, is considered to be a major inhibitor of axonal regeneration and is known to participate in the activation of the inflammatory response. The isolated CSPG has a molecular mass of 500-600 kDa and carries the HNK-1 (a glycan that could be found in a number of neural cell adhesion molecules) carbohydrate epitope. ${ }^{17} \mathrm{CSPG}$ is expressed in the glial scar $^{18}$ and significantly contributes to the nonpermissive properties of the CNS environment during axonal regeneration. Chondroitin sulfate moieties of the proteoglycans were shown to be involved in patterning the early phase of axonal growth across the midline and at a later stage controlling the axon divergence at the chiasm. ${ }^{19}$ A study on zebrafish also showed that CSPGs contribute to repellent axon guidance during regeneration of the optic projection. ${ }^{20}$ In adult rats, the microcrush lesion site of the $\mathrm{ON}$ was CSPG-immunoreactive and an adjacent GFAP-negative zone developed early after the lesion. Axons regrew towards the lesion, but most of them stopped abruptly at the glial scar. CSPG-positive scar and the myelin-derived growth inhibitory proteins contribute to the failure of in vivo RGC regeneration after injury. ${ }^{21}$
The Rho/ROCK pathway mediates the inhibitory activity of neurite growth associated with CSPGs of the CNS glial scar. Concomitant application of chondroitinase ABC and ROCK inhibitors may make optic fibers pass over barriers in the severely injured ON. Inhibition exerted by CSPGs in vitro can be blocked by application of either $\mathrm{C} 3$ transferase, a specific inhibitor of the Rho GTPase, orY27632, a specific inhibitor of the Rho kinase. RGC axon growth on glial scar tissue was enhanced in the presence of C3 transferase and Y27632, respectively. ${ }^{22}$ Suppressing the kinase function of the EGFR blocks the activities of both myelin inhibitors and CSPGs in inhibiting neurite outgrowth. In addition, regeneration inhibitors trigger the phosphorylation of EGFR in a calcium-dependent manner. Local administration of EGFR inhibitors promotes significant regeneration of injured $\mathrm{ON}$ fibers, pointing to a promising therapeutic avenue for enhancing axonal regeneration after CNS injury (for a summary of main inhibitors of RGC axon regeneration, Table 1).

The adoptive transfer of $\mathrm{T}$ cells specific to proteins associated with CNS myelin, such as myelin basic protein, can reduce the posttraumatic secondary degeneration of the rat ON. The synthetic peptide copolymer 1 (Cop-1), known to suppress experimental autoimmune encephalomyelitis, can be safely substituted for the natural myelin antigen in both passive and active immunizations for neuroprotection of the injured ON. ${ }^{23}$ Protection from glutamate toxicity requires reinforcement of the immune system by antigens that are different from those associated with myelin. The use of Cop-1 apparently circumvents this antigen specificity barrier. In the rat ocular hypertension model, immunization with Cop-1 significantly reduced the RGC loss without affecting the intraocular pressure. ${ }^{24}$ Vaccination was tried to enhance $\mathrm{ON}$ regeneration because myelin-derived inhibitors

Table I A summary of main inhibitors of axonal regeneration of RGCs and their blockers

\begin{tabular}{ll}
\hline Inhibitors & Strategies that block the inhibitors \\
\hline $\begin{array}{l}\text { Myelin-derived inhibitors } \\
\text { Nogo-A }\end{array}$ & $\begin{array}{l}\text { Anti-Nogo-A antibody or expression of } \\
\text { a dominant-negative form of the Nogo } \\
\text { receptor } \\
\text { RNA interference, interfering with the } \\
\text { intracellular signaling pathway such as } \\
\text { Rho/ROCK and SCH vaccination } \\
\text { Chogo receptor }\end{array}$ \\
MAG & $\begin{array}{l}\text { of MAG } \\
\text { A matrix-derived inhibitor }\end{array}$ \\
CSPG & Chondroitinase ABC \\
\hline
\end{tabular}

Abbreviations: CSPG, chondroitin sulfate proteoglycan; MAG, myelin-associated glycoprotein; RGCs, retinal ganglion cells; ROCK, rho-associated coil-forming protein kinase; $\mathrm{SCH}$, spinal cord homogenate. 
were discovered. Spinal cord homogenate $(\mathrm{SCH})$ contains abundant myelins. Enhanced axonal regeneration of RGCs was found after ON microcrush in SCH-vaccinated animals. In culture, serum from $\mathrm{SCH}$-vaccinated animals promoted the neurite growth of RGCs on myelin but not on CSPG..$^{25}$

\section{Neurotrophic factors}

Lack of neurotrophic factors is also a crucial reason for RGC death and axonal regeneration in ON injury or diseases. In support of RGC survival, neurotrophic supplement is a traditional and effective strategy.

Several neurotrophic factors such as brain-derived neurotrophic factor (BDNF) and neurotrophin-4 or 5 (NT$4 / 5$ ) are found to be effective not only for rescuing RGCs from retrograde cell death, but also for promoting growth of intraretinal axons. ${ }^{26} \mathrm{~A}$ single injection of BDNF or the prolonged administration of NT-4/ 5 by mini-pump increases the median lengths of axon branches after ON transection in adult rats, but neurotrophin-3 (NT-3) does not significantly influence axonal regrowth. ${ }^{27}$ Negishi et al compared the effect of grafts combining with trophic factors on ON regeneration in adult rats and found that the degree of regeneration was significantly increased by BDNF and NT-4 in the grafts and in the vitreous. They showed that neurotrophin receptors (tropomyosin receptor kinase [Trk]-A and Trk-B) were detected in nerve fibers in both retina and graft. ${ }^{28}$ On the axonal regeneration by $\mathrm{PN}$ transplantation in cats, a combined injection of BDNF, CNTF, and forskolin resulted in a 3.4-fold increase of beta-RGCs with regenerating axons. Watanabe et al suggested that the increase of regenerating beta-RGCs was mainly due to the enhanced effect of neurotrophic factors on their survival, and possibly to a change of RGC properties by cAMP to facilitate their axonal regeneration. ${ }^{29}$

Inhibition of CNS axon growth is mediated in part by calcium-dependent phosphorylation of axonal EGFR. A local administration of EGFR kinase inhibitors AG1478 and PD168393 to an ON lesion site can promote axonal regeneration of adult RGCs. However, Douglas et al showed that EGFR was neither constitutively expressed, nor activated in the $\mathrm{ON}$ axons in non-regenerating and regenerating ON injury models. Neurotrophins released by AG1478 stimulated disinhibited axonal growth of RGCs in CNS myelin-treated cultures by the induction of regulated intramembranous proteolysis of p75(NTR) and Rho inactivation. They attributed AG1478-stimulated neuritogenesis to the induced release of neurotrophins together with raised cAMP levels in treated cultures, leading to axon growth and disinhibition by neurotrophin-induced regulated intramembranous proteolysis of p75(NTR). These off-target effects of EGFR kinase inhibition suggest a novel therapeutic approach for the regeneration of CNS including RGC axons. ${ }^{30}$

BDNF released from RGCs acts as a survival factor for postsynaptic neurons in retinal target fields. ${ }^{31} \mathrm{BDNF}$ protects RGCs from apoptosis mediated by transient ischemia through inhibition of c-Jun and caspase- 2 activities. ${ }^{32}$ BDNF concentration dependently improved the survival of cultured RGCs, particularly of those small RGCs. ${ }^{33}$ The number of BDNF-positive RGCs increased 2-fold 2 days after axotomy, and the percentage of RGCs expressing TrkB was elevated by 50\%, while the number of TrkApositive RGCs doubled after axotomy in comparison to the controls. ${ }^{34}$ Insulin-like growth factor-I, an important factor in retinal development, prevents secondary death of RGCs after axotomy via phosphoinositide 3-kinase (PI3K)dependent protein kinase B (AKT) phosphorylation and by inhibition of caspase- $3 .{ }^{35}$ In the mature retina, CNTF treatment, via Janus kinase/signal transducers and activators of transcription signaling, enhances survival of RGCs and photoreceptor cells exposed to otherwise lethal perturbation. ${ }^{36}$ Adenovirus (ADV)-mediated CNTF expression in rat RGCs enhances RGC survival after ON transection. ${ }^{37}$ The protective effect of CNTF may result from activation of its high-affinity receptor expressed in RGCs, that switches the state of RGCs into more neuroprotective phenotype. CNTF also modulates glial cells in the retina and may buffer the high concentration of glutamate. ${ }^{38}$

The ways to supply neurotrophic factors in vivo include systemic application, intravitreal injection, and virus-mediated gene transfection. For instance, systemic application of glial cell-line-derived neurotrophic factor (GDNF) was reported to rescue some RGCs from axotomy. Using electrophoration, GDNF gene transferred into RGCs can increase RGC survival 2-4 weeks after ON transection. ${ }^{39}$ Administration of adeno-associated virus (AAV) vector expressing CNTF into the eyes protects RGCs undergoing focal injury and local ischemia in rats. ${ }^{40} \mathrm{AAV}$ containing basic fibroblast growth factor (bFGF) or BDNF is neuroprotective to RGCs from excitatory injury caused by $N$-methyl-D-aspartic acid (NMDA) or nerve crush. ${ }^{41}$

Besides injection of neurotrophic factors and increase of gene expression mediated by virus vectors, olfactory ensheathing cells (OECs) transplanted into the injured ON also increase beneficial neurotrophic factors like BDNF to promote RGC survival in rats, ${ }^{42}$ and an in vitro study demonstrated that it is BDNF produced by OECs that can enhance the survival of injured RGCs. ${ }^{43}$ 
Cui et al compared several neurotrophins including BDNF, NT-4/5, FGF, and GDNF, and concluded that CNTF is the only effective factor that promotes a long-distance axonal regeneration of RGCs, whereas BDNF and NT- $4 / 5$ can only enhance neurite sprouting within the retina. ${ }^{44,45}$ To enhance the $\mathrm{ON}$ regeneration, neurotrophin synergy is required. Logan et al demonstrated that a combination of basic FGF, NT-3, and BDNF delivered to the somata of RGCs promoted greater neuronal survival and axonal growth than each neurotrophic factor alone. They showed that the triple, but not single, neurotrophin treatment may decrease 30\% RhoA activation, and thus increase axonal regeneration. ${ }^{46}$ Many approaches promoting $\mathrm{ON}$ regrowth are combination of neurotrophic factors and other ways such as PN transplantation, lens injury, and chondroitinase application (for a summary of main neurotrophic factors, see Table 2).

\section{Factors related to lens injury}

Mansour-Robaey et al discovered that an injury on the lens secretes unidentified factors which promote neuronal survival and axonal regeneration of RGCs. ${ }^{47}$ Further investigations showed that such a lens injury also resulted in re-innervation of the visual center ${ }^{48}$ and recovery of visual evoked potentials. ${ }^{49}$

Macrophage activation by lens injury appeared to play a key role, because intraocular injections of zymosan, a yeast cell wall preparation, stimulated monocytes in the absence of the lens injury and induced RGCs to regenerate their axons into the distal ON or a PN graft. ${ }^{50}$ The axonal growth of RGCs is also enhanced by delaying macrophage activation for a few days after $\mathrm{ON}$ transection. ${ }^{51}$ Oncomodulin is a calcium-binding protein secreted intravitreally in combination with cAMP by macrophages, and accumulates rapidly in the eye after intravitreal inflammation and exhibits cAMP-dependent, high-affinity binding to a cell surface receptor on RGCs. Oncomodulin promotes axonal regeneration of RGCs possibly regulated

Table 2 A summary of main neurotrophic factors that enhance the neuronal survival and axonal regeneration of RGCs

\begin{tabular}{ll}
\hline Neurotrophic factors & Effects of the factors \\
\hline BDNF and NT-4/5 & $\begin{array}{l}\text { Rescuing RGCs from retrograde cell death } \\
\text { and promoting growth of intra-retinal axons } \\
\text { Enhancing survival of RGCs. The only } \\
\text { effective factor that promotes a long-distance } \\
\text { axonal regeneration of RGCs } \\
\text { Rescuing some RGCs }\end{array}$ \\
GDNF & Protecting RGCs \\
\hline bFGF &
\end{tabular}

Abbreviations: BDNF, brain derived neurotrophic factor; bFGF, basic fibroblast growth factor; CNTF, ciliary neurotrophic factor; GDNF, glial cell-line-derived neurotrophic factor; NT-4/5, neurotrophin-4 or 5; RGCs, retinal ganglion cells. through mammalian sterile 20-like kinase-3b, a homolog of a yeast kinase ${ }^{52,53}$ and is potentiated by both the sugarman-nose found in vitreous humor and forskolin-stimulated cAMP elevation. ${ }^{51,54,55}$ However, one group observed that neuroprotective and axon growth-promoting effects of intraocular inflammation did not depend on oncomodulin or the presence of large numbers of activated macrophages. ${ }^{56}$

Astrocyte-derived CNTF and leukemia inhibitory factor are also the major contributors to the neuroprotective and axonal growth-promoting effects on mature RGCs caused by lens injury and zymosan. ${ }^{57,58}$ Muller reported that astrocyte-derived CNTF activated the STAT/JAK pathway and promoted RGC survival and axonal regeneration after lens injury. ${ }^{59}$ Alpha-crystallins of the beta/gamma superfamily are the lens-derived activators of cascades and mimic the effects of lens injury, which led to axonal regeneration after ON crush in rats. ${ }^{60}$

\section{Cyclic AMP}

The level of cAMP plays a role in modulating outgrowth of nervous system. Urbina et al found that cAMP level was crucial for retinal outgrowth and regeneration. Forskolin, a potential activator of adenylate cyclase system and biosynthesis of cAMP, decreased the outgrowth of post-crushed goldfish retina in a dose-dependent manner. ${ }^{61}$ In the guidance of growth cones of RGCs, cAMP was found involved in conversion of netrin-1-induced attraction of growth cones to repulsion. Höpker et al reported in Xenopus laminin or fragment of laminin that YIGSR converted netrin-1 attraction to repulsion of RGC growth cones, and low levels of cAMP in growth cones also led to such conversion. Moreover, the amount of cAMP decreased in the presence of laminin or YIGSR.${ }^{62}$ Years later, the same group demonstrated that a low level of cAMP developmentally and intrinsically regulated the aged axon responsiveness to netrin. ${ }^{63}$ Another negative regulator of RGC growth cone movement, Sonic hedgehog, may decrease the level of cAMP in growth cones. ${ }^{64}$

In the PN-grafted ON stump, a combinational intravitreal injection of neurotrophins such as BDNF, CNTF, and forskolin may increase neuronal survival and axonal regeneration of RGCs, and the cAMP elevation by forskolin may contribute to the promotion of the $\mathrm{RGC}$ regenerative profile. ${ }^{29}$ Some small molecules including mannose and glucose were proved to have the effect of promoting axonal regeneration of RGCs in a cAMP-dependent manner in the higher or lower vertebrates. ${ }^{54}$ High level of cAMP abrogates the ability of CNS molecules to inhibit axonal elongation. Using the ON crushing model in adult rats, Monsul et al showed that intra- 
ocular injection of cAMP analog dibutyryl-cAMP promoted ON regeneration without increasing RGC survival. Their study also proved that cAMP did not enable axons to undergo rapid, sustained, and lengthy elongation. ${ }^{65}$ In the cat ON crush model, elevation of intracellular level of cAMP by forskolin also promoted axonal regeneration beyond the crush site to some extent. ${ }^{66}$ Another cAMP analog 8-(4-chlorophenylthio)cAMP (CPT-cAMP) was unable to promote RGC axons to regenerate into the $\mathrm{PN}$ graft, but significantly potentiated CNTF-induced axonal regeneration. Blockade of cAMP pathway did not affect spontaneous RGC survival and regeneration but effectively blocked CNTF/CPT-cAMP induced survival and regeneration. The CNTF/CPT-cAMP effect was proved to be a result of multiple pathways actions, with protein kinase A (PKA) as an essential component. ${ }^{67}$ CPT-cAMP and PKA inhibitor accelerated and decelerated the rates of $\mathrm{ON}$ regeneration, respectively, and the inhibitor application altered the RGC axon guidance in vitro, suggesting that the therapeutic manipulation of cAMP should ensure topography and consequently functions. ${ }^{68}$

$\mathrm{X}$ cells, which are essential for acute vision, suffer from rapid death after $\mathrm{ON}$ transection but can be rescued by intravitreal application of neurotrophins accompanied with elevation of cAMP. ${ }^{69}$ Astrocyte-derived CNTF and lens injury were proven to switch mature RGCs to a regenerative state following inflammation, and the drug potentiating the effect of lens injury may increase the intracellular cAMP level, thus resulting in strong axonal regeneration in vivo. ${ }^{59} \mathrm{Co}$-injection of CNTF with CPT-cAMP reduced CNTF-induced upregulation of suppressor of cytokine signal (SOCS) in both mRNA and protein, suggesting that cytokine-induced regenerative responses could be augmented by cyclic nucleotide in another way. ${ }^{70}$ SOCS overexpression may result in an overall reduction of axonal regrowth or even complete regeneration failure of RGC axons. ${ }^{71}$ The drug that inhibits cyclic nucleotide phophodiesterase was reported to increase RGC survival possibly through activating PKA signal. ${ }^{72}$ Microarray analysis in fish found that a member of cAMP-response element-binding protein family, activating transcription factor 3 , increased 8 -fold 24 hours after ON injury, indicating the mediator of $\mathrm{ON}$ regeneration gene expression in fish. ${ }^{73}$

\section{PTEN-mTOR signal}

Phosphatase and tensin homolog (PTEN) is a negative regulator of the mammalian target of rapamycin (mTOR) pathway. Mechanistic studies of axonal growth during development and axonal regeneration after injury reveal the PTEN-dependent molecular mechanism as a commonality.
Deletion of PTEN in adult RGCs promoted robust axonal regeneration after $\mathrm{ON}$ injury. In adult wild-type animals, the mTOR signal was suppressed significantly in axotomized RGCs and the protein synthesis was inhibited, leading to a limited axonal regeneration. By deletion of PTEN or tuberous sclerosis protein 1 , one of the protein complexes negatively regulating $\mathrm{mTOR}$, neuronal survival and axonal regeneration of RGCs were significantly enhanced after ON crushed, while administration of rapamycin, the mTOR inhibitor, significantly neutralized the survival and regeneration of RGCs in PTEN deletion. All these findings suggest that mTOR signal is sufficient to promote $\mathrm{ON}$ regeneration. ${ }^{2}$

PTEN antagonizes PI3K and catalyzes conversion from phosphatidylinositol 3,4,5-trisphosphate (PIP3) to PIP2, thus inactivation of PTEN results in PIP3 accumulation and activation of AKT which has many downstream effectors and is located in the soma and axon terminals of neurons. Those PI3K/AKT effectors may cooperate with other pathways to promote injured axonal regeneration. Meanwhile, PTEN controls several downstream signals such as 3-phosphorylated phosphoinositides, glycogen synthesis kinase, and mTOR, which are crucial for axonal growth.

Intriguing questions about PTEN relating to CNS regeneration are still open, such as how the pathway is regulated during development and after injury, what other possible signals work in concert to promote axonal regrowth, and the extension of functionality of new connection resulting from PTEN manipulation. Studies in answering these questions will make important steps to understand the factors underlying CNS regeneration. ${ }^{74}$

\section{Lithium}

Lithium was found to have protective effects on the nervous system. Lithium treatment caused Bcl-2 expression in injured RGCs of neonatal mouse retina in a dose-dependent manner, and depleting or forcing Bcl-2 expression deleted the protective effects of lithium. ${ }^{75}$ Later on, lithium protection to RGCs and axons was proved also in adult rats with ON crush. ${ }^{76}$ Lithium and other drugs have been treated as pharmaceutical approach to promote $\mathrm{ON}$ regeneration in animals. ${ }^{77}$ To obtain further $\mathrm{ON}$ regeneration, those authors suggested to use lithium together with other drugs, citicoline, for instance, that mediate induction of permissive environment in the adult CNS.

Increasing studies documented more mechanisms of lithium protection to the CNS, including the spinal cord and ON. Through Bcl-2 expression, lithium reinforced the promoting effect of chondrointinase $\mathrm{ABC}$ that digests $\mathrm{CSPG}$, the main 
ingredient of scar. ${ }^{78}$ In addition, lithium could activate Wnt or beta-catenin signaling to facilitate healing of bone fracture. ${ }^{79}$ While wnt signaling is also crucial for retinal development, ${ }^{80}$ activation of Wnt signaling by lithium was proved protective to RGCs under elevated pressure ${ }^{81}$ or excitotoxic damage. ${ }^{82}$

\section{Gene therapy}

Besides genes encoding neurotrophins mentioned before, anti-apoptosis genes (such as bcl-2, bcl-xL, p35 and caspase inhibitors) were efficiently upregulated by ADV transduction, human immunodeficiency virus transactivator of transcription containing a protein transduction domain, and AAV vector into the ON stump or vitreous body. Those genes coding apoptotic proteins including BAX, apoptotic protease activating factor, and immediate early gene $c$-Jun can be downregulated by small interference RNA. Increasing studies documented that the regulations of these genes effectively promote the survival and/or viability of injured RGCs. In methodology, non-virus vectors are usually safer than virus vectors, but non-virus approaches are not sufficient because the expression is transient and needs multiple injections. Even the expression of ADV-coding genes is transient and requires modifying. Many groups reported that AVV provided relatively long-term gene transduction of a large proportion of adult RGCs. ${ }^{1}$

When gene-activated matrices (GAM) are placed between the proximal and distal stumps of severed rat ONs, DNA is retained within the GAM, promoting sustained transgene expression in the ON, in the GAM itself, and, more importantly, in axotomized RGCs. Plasmids that encode bFGF, BDNF, and NT-3 promote sustained survival of RGC for over 3 months after the initial injury. These findings suggest that immobilized DNA implanted into a CNS lesion will be delivered by axon terminal uptake and retrograde transport to axotomized neurons. GAM may therefore be a useful agent for promoting the survival and axonal regeneration of sustained neurons. Further optimization of the matrices, plasmids, promoters, and genes present in the GAM will promote even more survival or, alternatively, axonal regeneration remains to be determined.

\section{Cell and tissue transplantation}

Tissue engineering develops scaffolds to serve as a bridge to guide and help injured nerve grow through the injury site. Using a PN graft as a scaffold is also helpful. ${ }^{83}$ Moreover, cell transplantation offers not only source of cells substantial to the lost cells caused by injury, but constant sources of neurotrophic factors produced by transplanted cells.
As increasing sorts of cells have been discovered and are available, it becomes feasible to supply RGC pool with transplanted and thereafter differentiated stem cells to replace the lost or dying host RGCs. Embryonic stem cells from eye-like structure differentiated into RGC-like cells and regenerate a new RGC layer after transplanted into the mouse eyes in the presence of NMDA. ${ }^{84}$ Unfortunately, more studies showed that stem cells failed to migrate or express the RGC marker after transplanted into the eyes, even some of the grafted stem cells differentiated and formed synapses with host cells. There exist many problems in the replacement of RGCs with transplanted cells, including transplant timing, interaction between intrinsic factors of RGCs, and the microenvironment of retinas. ${ }^{1}$ However, many studies indicate that cell transplantation-facilitated $\mathrm{ON}$ regeneration or repair is not attributed to cell replacement but via released neurotrophins from grafted cells. ${ }^{85-87}$

Since scientists noticed the difference in the regenerative ability between the central and peripheral nervous systems, studies have been set off to explore the possibility of axonal regeneration of central neurons when the surrounding microenvironments were replaced with the PN grafts.

\section{PN transplantation}

Tello was the pioneer to transplant PN onto the ON stump to induce axonal regeneration in rabbits, though the outcome of the ON regeneration was not fully confirmed at his time. ${ }^{88}$ Using modern axonal tracing technique, So and Aguayo finally demonstrated that transected RGC axons can regrow along a PN graft. ${ }^{83}$ Interestingly, axotomy seems to be the prerequisite for the regrowth of RGC axons, for intact RGCs would not extent their axon to the PN graft, ${ }^{89}$ which is consistent with later research that uninjured RGCs do not respond to protective neurotrophic factors like BDNF. ${ }^{90}$

The regrowth of RGC axons in the PN graft is distancedependent. The farther the transplantation site of the $\mathrm{PN}$ graft onto the $\mathrm{ON}$ stump is, the less the regrowth of RGC axons occurs. ${ }^{91}$ This phenomenon possibly attributes to the longer time for the diffusible trophic factors produced by Schwann cells in the PN graft to reach the soma of RGCs. Thus, the longer the distance of the remaining ON stump, the more difficult for those factors to reach the soma of RGCs resulting in a decreasing effect of the $\mathrm{PN}$ on regeneration of the RGC axons. ${ }^{92}$ Pre-degeneration was shown to enhance the axonal regeneration of RGCs in the PN graft, and the number of regenerating RGCs also depends on the time of transplantation after injury. You et al reported that the number of regenerating RGCs decreased with increased delay time, 
and pre-degenerated PN grafts overcome this adverse effect to some degree in the rats. To obtain the highest number of regenerating RGCs, pre-degenerated PN should be grafted immediately after ON lesion. ${ }^{93}$

Bray et al documented in rats that replacement of the $\mathrm{ON}$ with an autologous PN segment made axotomized RGCs regrow axons into a PN graft, and some of the regenerating axons can even reach the superior colliculus (SC) with terminals forming synaptic contact with SC neurons. ${ }^{94} \mathrm{PN}$ may serve as a bridge which links axotomized RGC to the brainstem, pretectum, or $\mathrm{SC}$, and guide regenerating axons to these target areas 8-13 months later. ${ }^{95}$ Recording from the neurons in SC showed that normal light field can induce postsynaptic potential, ${ }^{96,97}$ indicating these synapses are functional.

The underlying mechanisms for the enhancement of axonal regeneration of axotomized RGCs by PN grafts are as follows: 1) the replacement of injured ON with transplanted $\mathrm{PN}$ grafts deletes the inhibitory factors that exist in $\mathrm{ON}$ as these inhibitory factors are not presented in the PN grafts; 2) a PN graft containing Schwann cells which secrete neurotrophic factors that could diffuse to RGC axons. These factors are also protective to RGC somata and enhance RGC survival; 3) Schwann cells would proliferate and form columns after injury, and the basement membranes of the Schwann cell tubes possess many adhesion molecules such as L1, $\mathrm{J} 1,{ }^{98}$ integrins, and laminins, which are beneficial to axonal regeneration.

Although the axons of injured RGCs can be induced to regenerate along a PN graft, the number of regenerated RGCs is limited. Axons of alpha RGCs regrow faster into the PN graft than those of other types of RGCs. ${ }^{99}$ Quantitative studies showed that regenerating axons of RGCs are around $1 \%-10 \%$ of total cell population, according to various reports using rodents and cats, ${ }^{100}$ and this number decreased over time. To improve the regeneration of RGC axons, many modified methods of PN transplantation emerged. One of the methods is to reconstruct the PN graft by Schwann cells with lentiviral-mediated transfer of CNTF. This modification significantly enhanced neuronal survival as well as the axonal regrowth of injured RGCs, because the regenerating axons were found myelinated. ${ }^{101}$ Using a PN-to-ON graft model, You et al combined gene therapy with pharmacotherapy to promote the long-distance regeneration of injured adult RGCs. Autologous sciatic nerve was sutured onto the transected $\mathrm{ON}$ and the distal end immediately inserted into contralateral SC. In experimental groups, three bi-cistronic AAV vectors encoding CNTF were injected into different regions of the grafted eye. Each vector encoded a different fluorescent reporter to assess retinotopic order in the regenerate projection. To encourage sprouting/synaptogenesis, after 6 weeks some AAV-CNTF injected rats received an intravitreal injection of recombinant BDNF or AAV-BDNF. Four months after surgery, cholera toxin $B$ was used to visualize regenerate RGC axons. RGC viability and axonal regrowth into SC were significantly greater in AAV-CNTF groups. In some cases, near the insertion site, regenerate axonal density resembled retinal terminal densities seen in normal SC. Complex arbors were seen in superficial but not deep SC layers and many terminals were immunopositive for presynaptic proteins vGlut2 and SV2. There was improvement in visual function via the grafted eye with significantly greater pupillary constriction in both AAV-CNTF+BDNF groups. In both control and AAV-CNTF+rBDNF groups, the extent of light avoidance correlated with the maximal distance of axonal penetration into superficial SC. Despite the robust regrowth of RGC axons back into the $\mathrm{SC}$, axons originating from different parts of the retina were intermixed at the PN graft/host SC interface, indicating that there remained a lack of order in this extensive regenerate projection. ${ }^{102}$

Immunoreaction in the RGC axon environment is an essential condition for ON regeneration. Following ON transaction, there is an increase in the numbers of the total and active forms of microglial cells, the phagocytic cells, in the ON stump and retina. PN transplantation onto the freshly-cut ON stump and application of microglia inhibitor minimized the overall regeneration, suggesting an effect of microglial phagocytosis on the ON regeneration. ${ }^{103}$ Macrophages, another kind of phagocytic immune cell, also seem to play a beneficial role in axonal regeneration of RGCs. Lens injury leads to activation of macrophages that produce factors to promote the axonal regeneration of RGCs in the PN graft after ON injury. Such effect could also be obtained by application of Zymosan, a yeast cell wall preparation, which stimulates macrophages even better than lens injury. None of the secretion of macrophages is positive to enhance ON regrowth, some negative factors exist as well. The optimal effect of macrophages might be regulated by timing of macrophage activation. ${ }^{51}$

Another problem of $\mathrm{PN}$ transplantation is that autologous grafts may exacerbate the $\mathrm{PN}$ dysfunction. Cui et al proposed chimerical graft which could be derived from donor or host freeze-thawed PN and repopulated with cultured Schwann cells or OECs. This approach may provide an alternative in clinic. ${ }^{104}$ Allograft could be available in the presence of immunosuppressants such as FK506 and cyclosporin-A. In the absence of immunosuppressants, a PN allograft induced little axonal regrowth of RGCs in the grafts. ${ }^{105}$ 
RGCs could regenerate their injured axons to the PN graft, but those regenerating axons extend only few millimeters in the brain. In order to elevate the effectiveness of RGC axonal regrowth, many treatments and drugs need to be combined in future research. ${ }^{106}$

\section{Cell transplantation}

Cells have been transplanted into the eye to try to replace the dead RGCs or other lost cells after ON injury. ${ }^{107}$ Although stem cells were expected to differentiate and migrate to the injured site, there has not been any report to show that transplantation of stem cells could meet this demand up to date. However, plenty of studies found that transplanted stem cells facilitated ON repair and axonal regeneration via secreting trophic factors that play neuroprotective roles. ${ }^{108}$

Umbilical cord mesenchymal stromal cells were neuroprotective and promote axonal regeneration after being transplanted into the lesion site of the optic tract. An in vitro analysis proved that these cells secreted several immunomodulatory and neurotrophic factors including TGF beta-1, CNTF, NT-3, and BDNF. ${ }^{109}$ Neural stem and precursor cells derived from embryonic rat spinal cord contributed to the survival and axons regrowth of RGCs weeks after being transplanted into the lesion site of the optic tract in the neonatal rat. These cells secreted several neurotrophic factors in vitro but did not replace injured neurons as they did not express the marker of neural cells after transplantation. ${ }^{85}$ Research with chicken neural tube stem cells indicated that stem cells facilitated ON repair because the transplantation stimulated the expression of matrix metalloproteinase-2 (MMP-2) in the GFAP positive astrocytes in the $\mathrm{ON}$. This process is related to the degradation of inhibitory CSPGs leading to a more favorable microenvironment for axonal regeneration in the distal ON. ${ }^{86}$ In experimental glaucoma study, Johnson et al found that mesenchymal stromal cells transplanted into the vitreous could significantly increase the RGC survival, while systemic transplantation of the same cells was not neuroprotective. ${ }^{110}$

Oligodendrocytes precursor cells (OPCs) are multipotential and regarded as stem cells. NG2-expressing OPCs were positioned to inhibit axon growth of both developing and regenerating neurons. ${ }^{111}$ However, using the rat glaucoma model, it was found that OPCs were protective to RGCs axons when they interacted with inflammatory cells. ${ }^{112}$

Schwann cells are myelinating cells in the PN and play a key role in Wallerian degeneration and subsequent regeneration. Therefore, the transplantation of Schwann cells has been used to provide a modified environment of $\mathrm{ON}$ to enhance regeneration. ${ }^{113}$
Transplants of OECs are able to induce structural regeneration of severed axons from CNS neurons and restore neurological functions in rats. OEC transplantation has become one of the promising strategies in restoring lost functions of injured CNS. Both bulbar and nasal mucosal OECs prolong the survival of the explants. Counts of the surviving RGCs, identified by beta-III-tubulin immunohistochemistry and by their axon trajectory, show that the bulbar cell preparations exhibit around twice the potency of those from the mucosa. ${ }^{114}$ Moreno-Flores immortalized primary rat OECs using the SV40 large $T$ antigen expressed from a constitutive cellular promoter, and reported the isolation and characterization of clonal lines. Immortalized OECs have been shown to promote axonal regeneration of RGCs. ${ }^{115}$

An in vitro study showed that adult rat OECs were effective promoters of the neurite outgrowth of adult RGCs in coculture. This study also provided evidence for a contribution of an intracellular calcium signaling mechanism, possibly implicating ensheathing cell adhesion molecules in promoting neurite outgrowth ${ }^{116}$

In the first in vivo study of transplanted OEC into damaged $\mathrm{ON}$ by Li et al, unpurified GFP-positive OECs were obtained, embedded in a matrix of their own production and transplanted into a completely transected rat ON. These transplanted OECs survived within the $\mathrm{ON}$ and were able to stimulate and guide the axonal regeneration of cut RGCs for up to $10 \mathrm{~mm}$ into the distal stump. ${ }^{117}$ Although the regenerating axons were ensheathed by the transplanted cells, none of the regenerating axons became myelinated by either central or peripheral type myelin. They used the same operative procedure but transplanted Schwann cells instead of OECs. As with the OEC transplants, the Schwann cell transplants also induced regeneration of the severed RGC axons into the graft region. In contrast to the situation with the OEC transplants, however, a considerable number of the regenerating axons became myelinated by peripheral type myelin produced by the transplanted Schwann cells. ${ }^{118}$ Pastrana et al used microarrays to analyze three OEC populations with different capacities to promote axonal regeneration in cultured rat retinal neurons and identified a number of candidate genes that might play a role in promoting adult axonal regeneration, suggesting that MMP-2 does participate in adult axonal regeneration induced by OECs. ${ }^{119}$ Hayat et al demonstrated that pretreatment of OECs with pertussis toxin increased the number of subsequently cocultured adult RGCs which regrew neurites without affecting neuronal survival. The result supports the hypothesis that G-protein-regulated calcium signaling plays a significant role of OECs to support axonal regeneration of 
injured CNS. ${ }^{120}$ Chimeric PN grafts containing adult OECs do not promote regeneration of RGCs. ${ }^{104}$ However, an in vitro study showed that adult OECs, but not Schwann cells, promoted the long-distance growth of adult RGC neurites. ${ }^{121}$

A conditioned medium (CM) is the supernatant of culture medium in which cells have been cultured for a short period of time. The OEC-CM protected PC12 (cell line derived from a pheochromocytoma of the rat adrenal medulla) cells from $\mathrm{Zn}^{2+}$ insult, ${ }^{122,123}$ but was unable to protect normal cultured hippocampal neurons and RGCs. ${ }^{116,124}$ Wang demonstrated that such OEC-CM protected cultured RGCs from scratch insult, and neutralization of BDNF by a BDNF neutralizing antibody attenuated such neuroprotection of the medium. ${ }^{43}$

OEC in co-grafts had minimal impact on the target recognition of axons. OECs might be an appropriate cell type for direct transplantation into injured neuropil when attempting to stimulate the reconstruction of a specific pathway. ${ }^{125}$ Transplanted OECs have a particular potential within CNS neuropil because they can support axonal growth and also allow correct target innervation.

A mixture of OECs and fibroblasts cultured from the adult rat olfactory mucosa was transplanted through a scleral incision into the retina. Transplanted OECs have been shown to be incorporated into the $\mathrm{ON}$ head ensheathing RGC axons. ${ }^{126}$ OECs transplanted into the ocular stump of transected ON had a transient neuroprotective effect on axotomized RGCs. OEC transplantation induced the expression of BDNF in the ocular ON stump and retina and delayed the death of axotomized RGCs at a certain survival period (for a summary of main tissue and cells used for transplantation, Table 3).42

\section{Clinical neurorestorative strategies Medicine and factors}

Vitamin therapy has been suggested for several decades as a possible way to slow down the retinal degenerating process, but to date, there is no approved pharmacological therapy. The nerve growth factor is potential for the optic neuropathy. A study evaluated the pharmacokinetics of CNTF delivered by an intraocular encapsulated cell technology (ECT) implant in patients with retinitis pigmentosa (RP) and geographic atrophy. Results revealed that the intraocular ECT implant has a favorable pharmacokinetic profile for the treatment of chronic retinal degenerative diseases without systemic exposure. The researchers found that implants produced CNTF consistently over a 2-year period. The calculated half-life of CNTF in the vitreous continuously delivered by ECT implants was 51 months, with CNTF levels statistically equivalent between the 6- and 24-month implant periods. CNTF, anti-CNTF antibodies, and antibodies to the encapsulated cells were not detected in the serum of patients. ${ }^{127}$

\section{Cell transplantation}

Controlled human embryonic stem cell (hESC) differentiation resulted in $>99 \%$ pure retinal pigment epithelium (RPE). Schwartz et al performed two prospective clinical studies to study the safety and feasibility of subretinal transplantation of hESC-derived RPE in patients with Stargardt's macular dystrophy and dry age-related macular degeneration. Postimplantation, structural evidence demonstrated that the cells had attached and continued to persist for 4 months. There was no hyperproliferation, abnormal growth, or immunemediated transplant rejection. Best corrected visual acuity improved from hand motions to 20/800 in eye of the patient with Stargardt's macular dystrophy, and vision also improved in the patient with dry age-related macular degeneration. ${ }^{128}$

\section{Neuromodulation}

The Argus II epiretinal prosthesis has been developed to provide partial restoration of vision to subjects blinded from outer retinal degenerative disease. Safety and efficacy data support the development of higher resolution systems that target macular placement from implant design and surgical perspectives.

Table 3 A summary of main tissue and cells used for transplantation to enhance neuronal survival and axonal regeneration of RGCs

\begin{tabular}{ll}
\hline Tissue and cells used for transplantation & Effects \\
\hline PN graft & $\begin{array}{l}\text { Developing scaffolds as a bridge to guide injured ON through the lesion site and } \\
\text { secreting neurotrophic factors to enhance neuronal survival and axonal regeneration of } \\
\text { axotomized RGCs } \\
\text { Secreting immunomudulatory and neurotrophic factors, thus can protect injured RGCs } \\
\text { and promote axonal regeneration }\end{array}$ \\
Umbilical cord mesenchymal stromal cells & $\begin{array}{l}\text { Secreting neurotrophic factors } \\
\text { Neural stem and precursor cells }\end{array}$ \\
$\begin{array}{l}\text { Protecting RGC axons when interacting with inflammatory cells } \\
\text { Oligodendrocytes precursor cells }\end{array}$ & $\begin{array}{l}\text { Providing a modified environment of ON to enhance axonal regeneration } \\
\text { Secreting neurotrophic and cell adhesion factors, thus can protect injured RGCs and } \\
\text { Olfactory ensheathing cells }\end{array}$ \\
\end{tabular}

Abbreviations: ON, optic nerve; PN, peripheral nerve; RGCs, retinal ganglion cells. 
Currently, the device has been implanted in multiple subjects with profound RP. Most subjects showed an improvement in tasks assessing orientation and mobility, spatial-motor localization, and ability of discerning the direction of motion of moving stimuli. About one third of subjects experienced measurable improvement in visual acuity with the implant. ${ }^{129}$

In conclusion, from PN transplantation to PTEN-mTOR signals and epiretinal prosthesis, researchers have obtained much more insight of $\mathrm{ON}$ restoration and functional recovery. Due to the complexity of the CNS injury, combinational strategies are always the optimal choice, which will facilitate the restoration of the optic neuropathy.

\section{Acknowledgments}

Part of this work was funded by Dr. Si-Wei You's National Program on Key Basic Research Project of China (973 Program: 2014CB542202), by Dr. Fang Kuang's National Natural Foundation of China (81470631); and by Dr. Kwok-Fai So's National Program on Key Basic Research Project of China (973 Programs: 2011CB707501 and 2014CB542205); Leading Talents of Guangdong (2013), the Programme of Introducing Talents of Discipline to Universities (B14036), Project of International as well as Hong Kong, Macao \& Taiwan Science and Technology Cooperation Innovation Platform in Universities in Guangdong Province (2013gjhz0002), and Jinan University Guangdong-Hong Kong-Macau Cooperation and Innovation Center for Tissue Regeneration and Repair.

\section{Disclosure}

The authors report no conflicts of interest in this work.

\section{References}

1. Harvey AR, Hu Y, Leaver SG, et al. Gene therapy and transplantation in CNS repair: the visual system. Prog Retin Eye Res. 2006; 25(5):449-489.

2. Park KK, Liu K, Simth PD, et al. Promoting axon regeneration in the adult CNS by modulation of the PTEN/mTOR pathway. Science. 2008;322(5903):963-966.

3. Smith PD, Park KK, Cai B, et al. SOCS3 deletion promotes optic nerve. Neuron. 2009;64(5):617-623.

4. Cui Q, Cho KS, So KF, Yip HK. Synergistic effect of Nogo-neutralizing antibody IN-1 and ciliary neurotrophic factor on axonal regeneration in adult rodent visual systems. J Neurotrauma. 2004;21(5):617-625.

5. Su Y, Wang F, Zhao SG, Pan SH, Liu P, Teng Y, Cui H. Axonal regeneration after optic nerve crush in Nogo-A/B/C knockout mice. Mol Vis. 2008;14:268-273.

6. Su Y, Wang F, Teng Y, Zhao SG, Cui H, Pan SH. Axonal regeneration of optic nerve after crush in Nogo66 receptor knockout mice. Neurosci Lett. 2009;460(3):223-226.

7. Fischer D, He Z, Benowitz LI. Counteracting the Nogo receptor enhances optic nerve regeneration if retinal ganglion cells are in an active growth state. J Neurosci. 2004;24(7):1646-1651.

8. Chen C, Chen X, Yin X, Yuan R, Wang B, Ye J. NgR RNA interference, combined with zymosan intravitreal injection, enhances optic nerve regeneration. J Neurochem. 2009;110(5):1628-1634.
9. Ahmed Z, Suggate EL, Brown ER, et al. Schwann cell-derived factorinduced modulation of the $\mathrm{NgR} / \mathrm{p} 75 \mathrm{NTR} / \mathrm{EGFR}$ axis disinhibits axon growth through CNS myelin in vivo and in vitro. Brain. 2006;129(Pt 6): $1517-1533$.

10. Abdesselem H, Shypitsyna A, Solis GP, Bodrikov V, Stuermer CA. No Nogo66-and NgR-mediated inhibition of regenerating axons in the zebrafish optic nerve. J Neurosci. 2009;29(49):15489-15498.

11. Planchamp V, Bermel C, Tönges L, et al. BAG1 promotes axonal outgrowth and regeneration. Brain. 2008;131(Pt 10):2606-2619.

12. Bartsch S, Montag D, Schachner M, Bartsch U. Increased number of unmyelinated axons. Brain Res. 1997;762(1-2):231-234.

13. Dezawa M, Nagano T. Immunohistochemical localization of cell adhesion molecules and cell-cell contact proteins during regeneration of the rat optic nerve induced by sciatic nerve autotransplantation. Anat Rec. 1996;246(1):114-126.

14. Li C, Tropak MB, Gerlai R, et al. Myelination in the absence of myelin. Nature. 1994;369(6483):747-750.

15. Bartsch U. Myelination and axonal regeneration. J Neurocytol. 1996;25(5):303-313.

16. Wong EV, David S, Jacob MH, Jay DG. Inactivation of myelin. J Neurosci. 2003;23(8):3112-3117.

17. Xiao ZC, Bartsch U, Margolis RK, Rougon G, Montag D, Schachner $\mathrm{M}$. Isolation of a tenascin-R binding protein from mouse brain. $J$ Biol Chem. 1997;272(51):32092-32101.

18. Pizz MA, Elam JS. Characterization of a chondroitin sultate proteoglycan associated with regeneration. Neurochem Res. 2004; 29(4):719-728.

19. Chung KY, Taylor JS, Shum DK, Chan SO. Axon routing at the optic chiasm. Development. 2000;127(12):2673-2683.

20. Becker CG, Becker T. Repellent guidance. J Neurosci. 2002;22(3): 842-853.

21. Sellés-Navarro I, Ellezam B, Fajardo R, Latour M, McKerracher L. Retinal ganglion cell and nonneuronal cell responses to a microcrush lesion of adult rat optic nerve. Exp Neurol. 2001;167(2):282-289.

22. Monnier PP, Sierra A, Schwab JM, Henke-Fahle S, Mueller BK. The Rho/ROCK pathway mediates neurite growth-inhibitory activity associated with the chondroitin sulfate proteoglycans of the CNS glial scar. Mol Cell Neurosci. 2003;22(3):319-330.

23. Kipnis J, Yoles E, Porat Z, et al. T cell immunity to copolymer 1 confers neuroprotection on the damaged optic nerve: Possible therapy for optic neuropathies. Proc Natl Acad Sci U S A. 2000;97(13):7446-7451.

24. Schori H, Kipnis J, Yoles E, WoldeMussie E, Ruiz G, Wheeler LA, Schwartz M. Vaccination for protection of retinal ganglion cells against death from glutamate cytotoxicity and ocular hypertension: Implications for glaucoma. Proc Natl Acad Sci U SA. 2001;98(6):3398-3403.

25. Ellezam B, Bertrand J, Dergham P, McKerracher L. Vaccination stimulates retinal ganglion cell regeneration in the adult optic nerve. Neurobiol Dis. 2003;12(1):1-10.

26. Watanabe M, Sawai H, Fukuda Y. Survival of axotomized retinal ganglion cells in adult mammals. Clin Neurosci. 1997;4(5):233-239.

27. Sawai H, Clarke DB, Kittlerova P, Bray GM, Aguayo AJ. Brainderived neurotrophic factor and neurotrophin- $4 / 5$ stimulate growth of axonal branches from regenerating retinal ganglion cells. J Neurosci. 1996;16(12):3887-3894.

28. Negishi H, Dezawa M, Oshitari T, Adachi-Usami E. Optic nerve regeneration within artificial Schwann cell graft in the adult rat. Brain Res Bull. 2001;55(3):409-419.

29. Watanabe M, Tokita Y, Kato M, Fukuda Y. Intravitreal injections of neurotrophic factors and forskolin enhance survival and axonal regeneration of axotomized beta ganglion cells in cat retina. Neuroscience. 2003;116(3):733-742.

30. Douglas MR, Morrison KC, Jacques SJ, et al. Off-target effects of epidermal growth factor receptor antagonists mediate retinal ganglion cell disinhibited axon growth. Brain. 2009;132(Pt 11):3102-3121.

31. Caleo M, Menna E, Chierzi S, Cenni MC, Maffei L. Brain-derived neurotrophic factor is an anterograde survival factor in the rat visual system. Curr Biol. 2000;10(19):1155-1161. 
32. Kurokawa T, Katai N, Shibuki H, Kuroiwa S, Kurimoto Y, Nakayama C, Yoshimura N. BDNF diminishes caspase-2 but not c-Jun immunoreactivity of neurons in retinal ganglion cell layer after transient ischemia. Invest Ophthalmol Vis Sci. 1999;40(12):3006-3011.

33. Kashiwagi F, Kashiwagi K, Iizuka Y, Tsukahara S. Effects of brainderived neurotrophic factor and neurotrophin-4 on isolated cultured retinal ganglion cells: evaluation by flow cytometry. Invest Ophthalmol Vis Sci. 2000;41(8):2373-2377.

34. Hirsch S, Labes M, Bähr M. Changes in BDNF and neurotrophin receptor expression in degenerating and regenerating rat retinal ganglion cells. Restor Neurol Neurosci. 2000;17(2):125-134.

35. Kermer P, Klöcker N, Labes M, Bähr M. Insulin-like growth factor-I protects axotomized rat retinalganglion cells from secondary death via PI3-K-dependent Akt phosphorylation and inhibition of caspase-3 In vivo. J Neurosci. 2000;20(2):2-8.

36. Peterson WM, Wang Q, Tzekova R, Wiegand SJ. Ciliary neurotrophic factor and stress stimuli activate the Jak-STAT pathway in retinal neurons and glia. J Neurosci. 2000;20(11):4081-4090.

37. Weise J, Isenmann S, Klöcker N, Kügler S, Hirsch S, Gravel C, Bähr M. Adenovirus mediated expression of ciliary neurotrophic factor (CNTF) rescues axotomized rat retinal ganglion cells but does not support axonal regeneration in vivo. Neurobiol Dis. 2000;7(3):212-223.

38. van Adel BA, Arnold JM, Phipps J, Doering LC, Ball AK. Ciliary neurotrophic factor protects retinal ganglion cells from axotomyinduced apoptosis via modulation of retinal glia in vivo. J Neurobiol. 2005;63(3):215-234.

39. Ishikawa H, Takano M, Matsumoto N, Sawada H, Ide C, Mimura O, Dezawa M. Effect of GDNF genetransfer into axotomized retinal ganglion cells using in vivo electroporation with a contact lens-type electrode. Gene Ther. 2005;12(4):289-298.

40. MacLaren RE, Buch PK, Smith AJ, et al. CNTF gene transfer protects ganglion cells in rat retinae undergoing focal injury and branch vessel occlusion. Exp Eye Res. 2006;83(5):1118-1127.

41. Schuettauf F, Vorwerk C, Naskar R, et al. Adeno-associated viruses containing bFGF or BDNF are neuroprotective against excitotoxicity. Curr Eye Res. 2004;29(6):379-386.

42. Wu MM, Fan DG, Tadmori I, et al. Death of axotomized retinal ganglion cells delayed after intraoptic nerve transplantation of olfactory ensheathing cells in adult rats. Cell Transplant. 2010;19(2): 159-166.

43. Wang T, Cong R, Yang H, Wu MM, Luo N, Kuang F, You SW. Neutralization of BDNF attenuates the in vitro protective effects of olfactory ensheathing cell-conditioned medium on scratch-insulted retinal ganglion cells. Cell Mol Neurobiol. 2011;31(3):357-364.

44. Cui Q, So KF, Yip HK. Major biological effects of neurotrophic factors on retinal ganglion cells in mammals. Biol Signals Recept. 1998;7(4):220-226.

45. Cui Q, Lu Q, So KF, Yip HK. CNTF, not other trophic factors, promotes axonal regeneration of axotomized retinal ganglion cells in adult hamsters. Invest Ophthalmol Vis Sci. 1999;40(3):760-766.

46. Logan A, Ahmed Z, Baird A, Gonzalez AM, Berry M. Neurotrophic factor synergy is required for neuronalsurvival and disinhibited axon regeneration after CNS injury. Brain. 2006;129(Pt 2):490-502.

47. Mansour-Robaey S, Clarke DB, Wang YC, Bray GM, Aguayo AJ. Effects of ocular injury and administration of brain-derived neurotrophic factor on survival and regrowth of axotomized retinal ganglion cells. Proc Natl Acad Sci U S A. 1994;91(5):1632-1636.

48. Fischer D, Heiduschka $\mathrm{P}$, Thanos $\mathrm{S}$. Lens-injury-stimulated axonal regeneration throughout the optic pathway of adult rats. Exp Neurol. 2001; 172(2):257-272.

49. Heiduschka P, Fischer D, Thanos S. Recovery of visual evoked potentials after regeneration of cut retinal ganglion cell axons within the ascending visual pathway in adult rats. Restor Neurol Neurosci. 2005; 23(5-6):303-312.

50. Leon S, Yin Y, Nguyen J, Irwin N, Benowitz LI. Lens injury stimulates axon regeneration in the mature rat optic nerve. $J$ Neurosci. 2000; 20(12):4615-4626.
51. Yin Y, Cui Q, Li Y, Irwin N, Fischer D, Harvey AR, Benowitz LI. Macrophage-derived factors stimulate optic nerve regeneration. J Neurosci. 2003;23(6):2284-2293.

52. Irwin N, Li YM, O'Toole JE, Benowitz LI. Mst3b, a purine-sensitive Ste20-like protein kinase, regulates axon outgrowth. Proc Natl Acad Sci USA. 2006;103(48):18320-18325.

53. Lorber B, Berry M, Logan A. Different factors promote axonal regeneration of adult rat retinal ganglion cells after lens injury and intravitreal peripheral nerve grafting. J Neurosci Res. 2008;86(4):894-903.

54. Li Y, Irwin N, Yin Y, Lanser M, Benowitz LI. Axon regeneration in goldfish and rat retinal ganglion cells: differential responsiveness to carbohydrates and cAMP. J Neurosci. 2003;23(21):7830-7838.

55. Yin Y, Henzl MT, Lorber B, et al. Oncomodulin is a macrophagederived signal for axon regeneration in retinal ganglion cells. Nat Neurosci. 2006;9(6):843-852.

56. Hauk TG, Müller A, Lee J, Schwendener R, Fischer D. Neuroprotective and axon growth promoting effects of intraocular inflammation do not depend on comodulin or the presence of large numbers of activated macrophages. Exp Neurol. 2008;209(2):469-482.

57. Fischer D, Hauk TG, Müller A, Thanos S. Crystallins of the beta/ gamma-superfamily mimic the effects of lens injury and promote axon regeneration. Mol Cell Neurosci. 2008;37(3):471-479.

58. Leibinger M, Müller A, Andreadaki A, Hauk TG, Kirsch M, Fischer D. Neuroprotective and axon growth-promoting effects following inflammatory stimulation on mature retinal ganglion cells in mice depend on ciliary neurotrophic factor and leukemia inhibitory factor. J Neurosci. 2009;29(45):14334-14341.

59. Müller A, Hauk TG, Fischer D. Astrocyte-derived CNTF switches mature RGCs to a regenerative state following inflammatory stimulation. Brain. 2007;130(Pt 2):3308-3320.

60. Ying X, Zhang J, Wang Y, Wu N, Wang Y, Yew DT. Alpha-crystallin protected axons from optic nerve degeneration after crushing in rats. J Mol Neurosci. 2008;35(3):253-258.

61. Urbina M, Schmeer C, Lima L. 5HT1A receptor agonist differentially increases cyclic AMP concentration in intact and lesioned goldfish retina. In vitro inhibition of outgrowth by forskolin. Neurochem Int. 1996;29(5):453-460.

62. Höpker VH, Shewan D, Tessier-Lavigne M, Poo M, Holt C. Growthcone attraction to netrin-1 is converted to repulsion by laminin-1. Nature. 1999;401(6748):69-73.

63. Shewan D, Dwivedy A, Anderson R, Holt CE. Age-related changes underlie switch in netrin-1 responsiveness as growth cones advance along visual pathway. Nat Neurosci. 2002;5(10):955-962.

64. Trousse F, Martí E, Gruss P, Torres M, Bovolenta P. Control of retinal ganglion cell axon growth: a new role for Sonic hedgehog. Development. 2001;128(20):3927-3936.

65. Monsul NT, Geisendorfer AR, Han PJ, Banik R, Pease ME, Skolasky RL Jr, Hoffman PN. Intraocular injection of dibutyryl cyclic AMP promotes axon regeneration in rat optic nerve. Exp Neurol. 2004; 186(2):124-133.

66. Okada T, Ichikawa M, Tokita Y, Horie H, Saito K, Yoshida J, Watanabe M. Intravitreal macrophage activation enables cat retinal ganglion cells to regenerate injured axons into the mature optic nerve. Exp Neurol. 2005;196(1):153-163.

67. Park KK, Luo JM, Hisheh S, Harvey AR, Cui Q. Cellular mechanisms associated with spontaneous and ciliary neurotrophic factor-cAMPinduced survival and axonal regeneration of adult retinal ganglion cells. J Neurosci. 2004;24(48):10806-10815.

68. Rodger J, Goto H, Cui Q, Chen PB, Harvey AR. cAMP regulates axon outgrowth and guidance during optic nerve regeneration in goldfish. Mol Cell Neurosci. 2005;30(3):452-464.

69. Miyoshi T, Kurimoto T, Fukuda Y. Attempts to restore visual function after optic nerve damage in adult mammals. Adv Exp Med Biol. 2006; 557:133-147.

70. Park KK, Hu Y, Muhling J, et al. Cytokine-induced SOCS expression is inhibited by cAMP analogue: impact on regeneration in injured retina. Mol Cell Neurosci. 2009;41(3):313-324. 
71. Hellström M, Muhling J, Ehlert EM, Verhaagen J, Pollett MA, Hu Y, Harvey AR. Negative impact of rAAV2 mediated expression of SOCS3 on the regeneration of adult retinal ganglion cell axons. Mol Cell Neurosci. 2011;46(2):507-515.

72. Kashimoto R, Kurimoto T, Miyoshi T, et al. Cilostazol promotes survival of axotomized retinal ganglion cells in adult rats. Neurosci Lett. 2008;436(2):116-119.

73. Saul KE, Koke JR, García DM. Activating transcription factor 3 (ATF3) expression in the neural retina and optic nerve of zebrafish during optic nerve regeneration. Comp Biochem Physiol A Mol Integr Physiol. 2010;155(2):172-182.

74. Park KK, Liu K, Hu Y, Kanter JL, He Z. PTEN/mTOR and axon regeneration. Exp Neurol. 2010;223(1):45-50.

75. Huang X, Wu DY, Chen G, Manji H, Chen DF. Support of retinal ganglion cell survival and axon regeneration by lithium through a Bcl-2-dependent mechanism. Invest Ophthalmol Vis Sci. 2003;44(1): 347-354.

76. Schuettauf F, Rejdak R, Thaler S, et al. Citicoline and lithium rescue retinal ganglion cells following partial optic nerve crush in the rat. Exp Eye Res. 2006;83(5):1128-1134.

77. Cho KS, Chen DF. Promoting optic nerve regeneration in adult mice with pharmaceutical approach. Neurochem Res. 2008;33(10):2126-2133.

78. Yick LW, So KF, Cheung PT, Wu WT. Lithium chloride reinforces the regeneration-promoting effect of chondroitinase $\mathrm{ABC}$ on rubrospinal neurons after spinal cord injury. J Neurotrauma. 2004;21(7):932-943.

79. Li J, Khavandgar Z, Lin SH, Murshed M. Lithium chloride attenuates BMP-2 signaling and inhibits osteogenic differentiation through a novel WNT/GSK3-independent mechanism. Bone. 2011;48(2):321-331.

80. Liu H, Thurig S, Mohamed O, Dufort D, Wallace VA. Mapping canonical Wnt signaling in the developing and adult retina. Invest Ophthalmol Vis Sci. 2006;47(11):5088-5097.

81. Fragoso MA, Yi H, Nakamura RE, Hackam AS. The Wnt signaling pathway protects retinal ganglion cell 5 (RGC-5) cells from elevated pressure. Cell Mol Neurobiol. 2011;31(1):163-173.

82. Seitz R, Hackl S, Seibuchner T, Tamm ER, Ohlmann A. Norrin mediates neuroprotective effects on retinal ganglion cells via activation of the $\mathrm{Wnt} /$ beta-catenin signaling pathway and the induction of neuroprotective growth factors in Muller cells. J Neurosci. 2010;30(17):5998-6010.

83. So KF, Aguayo AJ. Lengthy regrowth of cut axons from ganglion cells after peripheral nerve transplantation into the retina of adult rats. Brain Res. 1985;328(2):349-354.

84. Aoki H, Hara A, Niwa M, Motohashi T, Suzuki T, Kunisada T. Transplantation of cells from eye-like structures differentiated from embryonic stem cells in vitro and in vivo regeneration of retinal ganglion-like cells. Graefes Arch Clin Exp Ophthalmol. 2008;246(2):255-265.

85. Hill AJ, Zwart I, Samaranayake AN, et al. Rat neurosphere cells protect axotomized rat retinal ganglion cells and facilitate their regeneration. J Neurotrauma. 2009;26(7):1147-1156.

86. Charalambous P, Hurst LA, Thanos S. Engrafted chicken neural tube-derived stem cells support the innate propensity for axonal regeneration within the rat optic nerve. Invest Ophthalmol Vis Sci. 2008;49(8):3513-3524.

87. Nishida A, Takahashi M, Tanihara H, et al. Incorporation and differentiation of hippocampus-derived neural stem cells transplanted in injured adult rat retina. Invest Ophthalmol Vis Sci. 2000;41(13):4268-4274.

88. Tello F. La influencia del neurotropismo en la regeneraçion de los centros nerviosos [The influence of neurotropism on the regeneration of nerve centers]. Trab Lab Invest Bio. 1911;9:124-159. Spanish

89. So KF, Xiao YM, Diao YC. Effects on the growth of damaged ganglion cell axons after peripheral nerve transplantation in adult hamsters. Brain Res. 1986;377(1):168-172.

90. Wang R, Xu J, Xie J, et al. Hyperbaric oxygen preconditioning promotes survival of retinal ganglion cells in a rat model of optic nerve crush. J Neurotrauma. 2010;27(4):763-770.

91. You SW, So KF, Yip HK. Axonal regeneration of retinal ganglion cells depending on the distance of axotomy in adult hamsters. Invest Ophthalmol Vis Sci. 2000;41(10):3165-3170.
92. So KF, Yip HK. Axonal regeneration in the central nervous system. In: Ingoglia NA and Murray M, editors. The Use of Peripheral Nerve Transplants to Enhance Axonal Regeneration in CNS Neurons. New York, NY: Marcel Dekker, Inc. 2001; Chapter 20:505-528.

93. You SW, Bedi KS, Yip HK, So KF. Axonal regeneration of retinal ganglion cells after optic nerve pre-lesions and attachment of normal or pre-degenerated peripheral nerve grafts. Vis Neurosci. 2002; 19(5):661-668

94. Bray GM, Villegas-Pérez MP, Vidal-Sanz M, Aguayo AJ. The use of peripheral nerve grafts to enhanceneuronal survival, promote growth and permit terminal reconnections in the central nervous system of adult rats. J Exp Biol. 1987;132:5-19.

95. Avilés-Trigueros M, Sauvé Y, Lund RD, Vidal-Sanz M. Selective innervation of retinorecipient brainstem nuclei by retinal ganglion cell axons regenerating through peripheral nerve grafts in adult rats. J Neurosci. 2000;20(1):361-374.

96. Keirstead SA, Rasminsky M, Fukuda Y, Carte DA, Aguayo AJ, VidalSanz M. Electrophysiologic responses in hamster superior colliculus evoked by regenerating retinal axons. Science. 1989;246(4927): 255-257.

97. Sauve Y, Gaillard F. Regeneration in the visual system of adult mammals. In: Kolb H, Fernandez E, Nelson R, editors. Webvision: The Organization of the Retina and Visual System (Internet). Salt Lake (UT): University of Utah Health Sciences Center; 1995.

98. Dezawa M, Kawana K, Adachi-Usami E. The role of Schwann cells during retinal ganglion cell regeneration induced by peripheral nerve transplantation. Invest Ophthalmol Vis Sci. 1997;38(7):1401-1410.

99. Maki H, Watanabe M, Tokita Y, Saito K, Yoshida J. Axons of alpha ganglion cells regenerate faster than other types into a peripheral nerve graft in adult cats. J Neurosci Res. 2003;72(2):218-226.

100. Fukuda Y, Watanabe M. Regeneration of cat's optic nerve and its functional recovery. Rev Bras Biol. 1996;56(Suppl 1 Pt 1):69-78.

101. Hu Y, Leaver SG, Plan GW, et al. Lentiviral-mediated transfer of CNTF to Schwann cells within reconstructed peripheral nerve grafts enhances adult retinal ganglion cell survival and axonal regeneration. Mol Ther. 2005;11(6):906-915.

102. You SW, Hellström M, Pollett MA, et al. Large-scale reconstitution of a retina-to-brain pathway in adult rats using gene therapy and bridging grafts: An anatomical and behavioral analysis. Exp Neurol. 2016;279:197-211.

103. Raibon E, Sauvé Y, Carter DA, Gaillard F. Microglial changes accompanying the promotion of retinalganglion cell axonal regeneration into peripheral nerve grafts. J Neurocytol. 2002;31(1):57-71.

104. Cui Q, Pollett MA, Symons NA, Plant GW, Harvey AR. A new approach to CNS repair using chimeric peripheral nerve grafts. J Neurotrauma. 2003;20(1):17-31.

105. Gillon RS, Cui Q, Dunlop SA, Harvey AR. Effects of immunosuppression on regrowth of adult rat retinal ganglion cell axons into peripheral nerve allografts. J Neurosci Res. 2003;74(4):524-532.

106. Watanabe M. Regeneration of optic nerve fibers of adult mammals. Dev Growth Differ. 2010;52(7):567-576.

107. Miller NR. Optic nerve protection, regeneration, and repair in the $21 \mathrm{st}$ century: LVIII Edward Jackson Memorial lecture. Am J Ophthalmol. 2001;132(6):811-818.

108. Dahlmann-Noor A, Vijay S, Jayaram H, Limb A, Khaw PT. Current approaches and future prospects for stem cell rescue and regeneration of the retina and optic nerve. Can J Ophthalmol. 2010;45(4): 333-341.

109. Zwart I, Hill AJ, Al-Allaf F, et al. Umbilical cord blood mesenchymal stromal cells are neuroprotective and promote regeneration in a rat optic tract model. Exp Neurol. 2009;216(2):439-448.

110. Johnson TV, Bull ND, Hunt DP, Marina N, Tomarev SI, Martin KR. Neuroprotective effects of intravitreal mesenchymal stem cell transplantation in experimental glaucoma. Invest Ophthalmol Vis Sci. 2010;51(4):2051-2059.

111. Chen ZJ, Negra M, Levine A, Ughrin Y, Levine JM. Oligodendrocyte precursor cells: reactive cells that inhibit axon growth and regeneration. J Neurocytol. 2002;31(6-7):481-495. 
112. Bull ND, Irvine KA, Franklin RJ, Martin KR. Transplanted oligodendrocyte precursor cells reduce neurodegeneration in a model of glaucoma. Invest Ophthalmol Vis Sci. 2009;50(9):4244-4253.

113. Dezawa M. Central and peripheral nerve regeneration by transplantation of Schwann cells and transdifferentiated bone marrow stromal cells. Anat Sci Int. 2002;77(1):12-25.

114. Dai C, Qin YZ, Li Y, Raisman G, Li D. Survival of retinal ganglion cells in slice culture provides a rapid screen for olfactory ensheathing cell preparations. Brain Res. 2010;1354:40-46.

115. Moreno-Flores MT, Lim F, Martín-Bermejo MJ, Díaz-Nido J, Avila J, Wandosell F. Immortalized olfactory ensheathing glia promote axonal regeneration of rat retinal ganglion neurons. $J$ Neurochem. 2003;85(4):861-871.

116. Sonigra RJ, Brighton PC, Jacoby J, Hall S, Wigley CB. Adult rat olfactory nerve ensheathing cells are effective promoters of adult central nervous system neurite outgrowth in coculture. Glia. 1999;25(3):256-269.

117. Li Y, Sauvé Y, Li D, Lund RD, Raisman G. Transplanted olfactory ensheathing cells promote regeneration of cut adult rat optic nerve axons. J Neurosci. 2003;23(21):7783-7788.

118. Li Y, Li D, Raisman G. Transplanted Schwann cells, not olfactory ensheathing cells, myelinate optic nerve fibres. Glia. 2007;55(3):312-316.

119. Pastrana E, Moreno-Flores MT, Gurzov EN, Avila J, Wandosell F, Diaz-Nido J. Genes associated with adult axon regeneration promoted by olfactory ensheathing cells: a new role for matrix metalloproteinase 2. J Neurosci. 2006;26(20):5347-5359.

120. Hayat S, Thomas A, Afshar F, Sonigra R, Wigley CB. Manipulation of olfactory ensheathing cell signaling mechanisms: effects on their support for neurite regrowth from adult CNS neurons in coculture. Glia. 2003;44(3):232-241.
121. Leaver SG, Harvey AR, Plant GW. Adult olfactory ensheathing glia promote the long-distance growth of adult retinal ganglion cell neuritis in vitro. Glia. 2006;53(5):467-476.

122. Wang YZ, Meng JH, Yang H, Luo N, Jiao XY, Ju G. Differentiationinducing and protective effects of adult rat olfactory ensheathing cell conditioned medium on PC12 cells. Neurosci Lett. 2003; 346(1-2):9-12.

123. Feng L, Meng H, Wu F, et al. Olfactory ensheathing cells conditioned medium prevented apoptosis. Int J Dev Neurosci. 2008;26(3-4): 323-329.

124. Pellitteri R, Spatuzza M, Russo A, Stanzani S. Olfactory ensheathing cells exert a trophic effect on the hypothalamic neurons. Neurosci Lett. 2007;417(1):24-29.

125. Vukovic J, Plant GW, Ruitenberg MJ, Harvey AR. Influence of adult Schwann cells and olfactory ensheathing glia. Neuron Glia Biol. 2007;3(2):105-117.

126. Li Y, Li D, Khaw PT, Raisman G. Transplanted olfactory ensheathing cells incorporated into the optic nerve head ensheathe retinal ganglion cell axons: possible relevance to glaucoma. Neurosci Lett. 2008;440(3):251-254.

127. Kauper K, McGovern C, Sherman S, et al. Two-year intraocular delivery of ciliary neurotrophic factor by encapsulated cell technology implants in patients with chronic retinal degenerative diseases. Invest Ophthalmol Vis Sci. 2012;53(12):7484-7491.

128. Schwartz SD, Hubschman JP, Heilwell G, et al. Embryonic stem cell trials for macular degeneration: a preliminary report. Lancet. 2012;379(9817):713-720.

129. Ahuja AK, Behrend MR. The Argus ${ }^{\mathrm{TM}}$ II retinal prosthesis: factors affecting patient selection for implantation. Prog Retin Eye Res. 2013;36:1-23.
Journal of Neurorestoratology

\section{Publish your work in this journal}

The Journal of Neurorestoratology is an international, peer-reviewed, open access online journal publishing original research and review articles on the subject of Neurorestoratology. To provide complete coverage of this revolutionary field the Journal of Neurorestoratology will report on relevant experimental research, technological advances,

\section{Dovepress}

and clinical achievements. The manuscript management system is completely online and includes a very quick and fair peer-review system, which is all easy to use. Visit http://www.dovepress.com/testimonials. php to read real quotes from published authors. 